\title{
Microbiological evaluation of mycotic keratitis in north Maharashtra, India: A prospective study
}

\author{
Varsha Tukaram Kalshetti ${ }^{1}$, Surendra P. Wadgaonkar², Viraj M. Bhate', Rahul G. Wadile1, \\ Neha Haswani', S.T. Bothikar ${ }^{1}$ \\ ${ }^{1}$ Department of Microbiology, ACPM Medical College, Dhule. (Maharashtra),India \\ ${ }^{2}$ Department of Opthalmology, ACPM Medical College, Dhule. (Maharashtra),India
}

\begin{abstract}
Objective: Corneal blindness is a major public health problem worldwide and mycotic keratitis is one of the predominant causes. Infection is difficult to treat and can lead to severe visual impairment or blindness. It is worldwide in distribution but is more common in tropics and subtropical region. Trauma is the major predisposing factor, followed by ocular or systemic defects, prior application of corticosteroids, and prolonged use of antibiotic eye drops. The purpose of this study was to document the clinical and epidemiological features and laboratory diagnosis of fungal corneal ulcer.

Methods: Patients who presented with clinically suspected corneal ulcer to ophthalmology department registered for the study. Data were collected through history and slit lamp examination. Corneal scrapping was performed. A portion of each scrapping was examined by direct microscopy. Another portion was inoculated directly on to solid culture media.
\end{abstract}

Results: This study included 40 subjects with corneal ulcer based on clinical suspicion, of whom 14 cases were diagnosed with mycotic keratitis in the laboratory. Among these 14 cases, culture showed fungal growth only in 12 cases where the remaining cases were positive only by Potassium hydroxide $(\mathrm{KOH})$ preparation. Males were more commonly affected and were mostly in the age group of 21 to 50 years. Aspergillus species and Fusarium species were the major isolates.

Conclusion: Rapid diagnosis and early institution of anti-fungal therapy is necessary to prevent ocular morbidity and blindness. The direct microscopy method by $\mathrm{KOH}$ is rapid, inexpensive and reliable method and culture helps in definite diagnosis and identification. J Microbiol Infect Dis 2015;5(3): 99-102

Key words: Mycotic keratitis, potassium hydroxide, Aspergillus species, Fusarium species.

\section{Hindistan, Maharashtra'da mikotik keratitlerin mikrobiyolojik değerlendirilmesi: Prospektif bir çalışma}

\section{ÖZET}

Amaç: Korneaya bağlı körlük bütün dünyada önemli bir halk sağlığı problemidir ve mikotik keratit önde gelen sebeplerinden biridir. Enfeksiyonun tedavi edilmesi zordur ve görme bozukluğuna ve körlüğe yol açabilir. Bu bütün dünyada görülebilmektedir ancak tropik ve subtropik bölgelerde yaygındır. Travma önemli kolaylaştıııc faktördür ve ardından oküler ve sistemik yetmezlikler, önce kortikosteroit uygulamaları ve antibiyotikli göz damlalarının uzun süre kullanımı gelir. Bu çalışmanın amacı fungal korneal ülserin klinik ve epidemiyolojik özelliklerini ve laboratuvar tanısını dökümante etmektir.

Yöntemler: Göz kliniğine klinik olarak korneal ülser şüphesi ile başvuran hastalar bu çalışmaya dahil edildi. Veriler hikayelerinden ve fizik muayene bulgularından toplandı. Korneal temizlik/ayıklama yapııdı. Çıkarılan her parça mikroskopta incelendi. Diğer bir parka doğrudan katı besiyerinde kültüre edildi.

Bulgular: Çalışmaya klinik olarak kornea ülseri olan 40 olgu dahil edildi, bu olguların 14'ü laboratuvarda mikotik keratit olarak teşhis edildi. Bu 14 olgunun 12'sinde kültürde mantar üremesi oldu, geri kalan olgularda yalnızca potasyum hidroksit $(\mathrm{KOH})$ preparatları pozitif idi. En çok etkilenenler 21-50 yaş arası erkekler idi. Aspergillus türleri ve Fusarium türleri en sık izole edilen türler idi.

Sonuç: Hızlı tanı ve antifungal tedavinin erken başlanması gözün hastalıktan ve körlükten kurtulabilmesi için önemlidir. $\mathrm{KOH}$ ile direkt mikroskopik metot hızlı, ucuz ve güvenilirdir ve kültür tanı konulmasına ve kesinleştirilmesine yardım eder.

Anahtar kelimeler: Mikotik keratit, potasyum hidroksit, Aspergillus türleri, Fusarium türleri

Correspondence: Varsha T. Kalshetti, Department of Microbiology, ACPM Medical College and Hospital, Sakri Road, Dhule, 424001 Maharashtra, India Email: vskanthikar@gmail.com 


\section{INTRODUCTION}

Fungal keratitis is a major ophthalmic problem. ${ }^{1}$ It has been found to account for $6 \%$ to $50 \%$ of all the cases of ulcerative keratitis. ${ }^{2,3}$ At least 70 genera of fungi have been associated with fungal keratitis. ${ }^{4}$ Of these, Fusarium species and Aspergillus species are responsible for $70 \%$ cases. ${ }^{5-7}$

Many microorganisms can cause infectious corneal ulcer. Among them are bacteria, fungi, viruses, protozoa, and chlamydia. Mycotic keratitis is an infection caused by fungus that leads to inflammation and ulceration. Ulceration ifs defined as a loss of corneal epithelium with underlined stromal infiltration and suppuration associated with signs of inflammation with or without hypopyon. It is frequently caused by trauma with vegetative material, other major risk factors are frequent use of broad spectrum antibiotics and steroids and increasing use of corneal contact lenses. ${ }^{8}$ The typical feature of fungal infection is slow onset and gradual progression, where signs are much more than symptoms. Satellite lesions around the ulcer are a common feature of fungal keratitis and hypopyon is usually seen.

Untreated, infective keratitis may lead to opacification and perforation of the cornea. Early diagnosis and treatment are important in preventing further complications such as hypopyon formation, endophthalmitis or loss of vision. . $^{911}$ However, due to potential serious complications from mycotic keratitis, it is important to know the exact etiology of corneal ulcer to institute appropriate therapy in time.

The purpose of this study is rapid diagnosis and early treatment. Although culture helps in definite diagnosis and identification, direct microscopical detection of fungal structures in corneal scrapping permits rapid presumptive diagnosis.

\section{METHODS}

A prospective study of corneal ulcer was conducted from October 2011 to November 2013. Forty clinically suspected cases of corneal scrapping were included in the study. A detailed history of present illness was undertaken on all patients with special references to occupation, trauma, medication to eye and surgical intervention, immunosuppression and use of cosmetics or therapeutic contact lenses.

The diagnostic material is harvested by an experienced ophthalmologists by taking the scrapping of cornea using a sterile Kimura spatula under slitlamp magnification after instillation of anesthetic eye drops. Material obtained from the base and edges were examined microscopically using freshly prepared potassium hydroxide $10 \%$ and Gram staining.

Corneal material was inoculated on two sets of Sabouraud's dextrose agar with antibiotics but without actidione were inoculated and incubated at $25^{\circ} \mathrm{C}$ and $37^{\circ} \mathrm{C}$, separately over a period of four weeks. The corneal material was also inoculated on two blood agar plates in the form of "C" and "S" shaped steaks on the plates. Fungal growth in the form of streak ensures that the growth is from the inoculum/ specimen rather than a laboratory contaminant. All inoculated media were incubated aerobically. Cultures were checked every day during the first week and twice a week for the next three weeks.

Microbial cultures were considered significant if, growth of the same organism was demonstrated on more than one solid-phase medium, and/or if there was a confluent growth at the site of inoculation on one solid medium, and/or if growth of one medium was consistent with direct microscopy findings and/ or if the same organism was grown from repeated scrapings. Any growth present on the medium was identified by standard laboratory techniques via the rate of growth, colony morphology and microscopic appearance in Lactophenol cotton blue mount and slide culture.

\section{RESULTS}

A total of 40 patients met the inclusion criteria of this study of whom $24(60 \%)$ were males and $16(40 \%)$ were females. Most patients were from rural areas. A high incidence of mycotic keratitis was observed from April to July. A larger group of patients were between the ages of 21 to 50 years. From total of 40 patients studied, fungal keratitis was identified as the principal etiological agent of corneal ulceration in $14(35 \%)$ patients (10 males and four females). $12(85.7 \%)$ samples grew fungus in culture while two corneal scrapings were positive for fungal elements only in direct microscopy and culture were negative. Seven $(50 \%)$ patients with fungal keratitis were farmers, three $(21.4 \%)$ laborer and four $(28.5 \%)$ were housewives. Corneal trauma was identified as the predominant predisposing factor. (Table1)

In culture Aspergillus species (06) and Fusarium species (05) were the major isolates. Aspergillus flavus was detected in three patients, Aspergillus nigor in two patients, Aspergillus fumigatus in one patient, Fusarium solani in 05 patients and Candida albicans in 01 patient. (Table 2) 
Table 1. Predisposing factors and Number of positive cases of mycotic keratitis.

\begin{tabular}{lcc}
\hline \multirow{2}{*}{ Predisposing factor } & \multicolumn{2}{c}{ Number of cases } \\
\cline { 2 - 3 } & $\begin{array}{c}\text { Total number of } \\
\text { cases studied }\end{array}$ & $\begin{array}{c}\text { Number of Positive } \\
\text { cases for fungus }\end{array}$ \\
\hline History of corneal trauma & 05 & 05 \\
Topical antibiotics/steroids & 02 & 01 \\
Surgery (Cataract) & 02 & 01 \\
Use of herbal medicine & 00 & 00 \\
Use of contact lens & 00 & 00 \\
No significant history & 05 & 05 \\
\hline
\end{tabular}

Table 2. Distribution of various fungal species in patients with mycotic keratitis.

\begin{tabular}{llc}
\hline Type of Fungus & Isolated species & Numbers \\
\hline Hyaline fungi & Aspergillus flavus & 3 \\
& Aspergillus niger & 2 \\
& Aspergillus fumigatus & 1 \\
& Fusarium solani & 5 \\
Yeast & Candida species & 1 \\
\hline
\end{tabular}

\section{DISCUSSION}

The fungal infection of eye are important amongst the clinical conditions responsible for ocular morbidity and blindness. In tropical countries including India, keratitis is the most frequently encountered fungal infection.

The incidence of fungal keratitis in this study was $35 \%$. Similar reported incidence in other regions of India are $7.3 \%$ in North India, ${ }^{12} 32 \%$ in East India, ${ }^{13} 38.9 \%$ in West India ${ }^{14}$ and $32 \%-39.8 \%$ in South India. ${ }^{15,16}$

On the other hand study conducted at University Hospital of Taiwan in 2004 reported an incidence of fungal keratitis in only $13.5 \%$ of 476 eyes with microbial corneal ulcer. ${ }^{17}$ which is quite lower than our study. In contrast to our study Mirshahi et al ${ }^{18}$ and Javadi et al ${ }^{19}$ reported $83 \%$ cases of fungal corneal ulcer which is much higher than our study. This regional variation could be because fungal keratitis is expected to be more common in the tropical and subtropical region than in the temperate region.

Higher incidence of Mycotic keratitis seen between ages of 21 to 50 years. Same was reported by Bharati et $\mathrm{al}^{20}$ and Ashok kumar Narsani et al. ${ }^{21}$ In our study, the majority of mycotic keratitis was due to filamentous fungi, namely Aspergillus and Fusarium species. Aspergillus species was the most common isolate in fungal keratitis reported by Chander et al. ${ }^{22}$ However, Fusarium species was found to be the most common cause of fungal keratitis from South India by Bharati et al ${ }^{20}$ and Srinivasan et al. ${ }^{15}$ Male patients are predominant $(60 \%)$ in our study. ${ }^{15,16,23-25}$ Higher incidence of fungal keratitis has also been reported among farmers. ${ }^{23-26}$

Corneal trauma has always been identified as a cause of microbial keratitis. ${ }^{15,20,26-27}$ Schaefer et al have also identified co-existing ocular disease as a major predisposing factor. ${ }^{28}$ The incidence of fungal keratitis is higher during the peak of time of agriculture activity. A hot, humid, windy climate and an agriculture-based occupation of a large population make fungal keratitis more frequent in tropical zones. ${ }^{16,21}$ In costal Karnataka (India), Higher incidence is reported in October, June and January ${ }^{29}$ and in Hyderabad, higher incidence of fungal keratitis is reported during winter (October to January) and monsoon (June to September) seasons. ${ }^{16}$

In conclusion, fungal corneal ulcer is common in India due to the tropical climate and a large agriculture-based occupation. Key element in the diagnosis of mycotic keratitis is the clinical suspicion by ophthalmologist. Rapid diagnosis and early institution of antifungal therapy is necessary to prevent ocular morbidity and blindness. Although culture helps in definitive diagnosis and identification, direct microscopic detection of fungal structures in corneal scrapes permit a rapid presumptive diagnosis.

\section{REFERENCES}

1. Rautaraya B, Sharma S, Kar S, et al. Diagnosis and treatment outcome of mycotic keratitis at a tertiary eye care center in Eastern India. BMC Ophthalmology 2011;11:39.

2. Panda A, Sharma N, Das G, et al. Mycotic keratitis in children: Epidemiological and microbiological evaluation. Cornea 1997;16:295-299.

3. Dunlop AA, Wright ED, Howlader SA, et al. Suppurative corneal ulceration in Bangladesh. A study of 142 cases examining the microbiological diagnosis, clinical and epidemiological features of bacterial and fungal keratitis. Aust N Z J Ophthalmol 1994 May;22:105-110.

4. Agarwal PK, Roy P, Das A, et al. Efficacy of topical and systemic itraconazole as a broad-spectrum antifungal agent in mycotic corneal ulcer. A preliminary study. Indian J Ophthalmol 2001;49:173-176.

5. Agrawal V, Biswas J, Madhavan $\mathrm{H} \mathrm{N}$, et al. Current perspectives in infectious keratitis. Indian J Ophthalmol 1994;42:171192.

6. Bennett JE. Diagnosis and treatment of fungal infections. In Fauci AS, Braunwald E Isselbacher KJ, et al , Editors. Harrison's Principles of Internal Medicine. 14th ed. New York: McGraw-Hill; 1998. Vol 1, pp 1148-1154. 
7. O'Day DM. Fungal keratitis. In: Pepose JS, Holland GN, Wilhemus KR, editors. Ocular infections and immunity. St.Louis: Mosby;1997. p 263-264.

8. Williamson J, Gordon AM, Wood R, et al. Fungal flora of the conjunctival sac in health and disease: influence of topical and systemic steroids. Br J Ophthalmol 1968;52:127-137.

9. Vemuganti GK, Garg P, Gopinathan U, et al. Evaluation of agent and host factors in progression of mycotic keratitis: $A$ histopathological and microbiological study of 167 corneal buttons. Ophthalmology 2002;109:1538-1546.

10. Poria V C, Bharad V R, Dongre D S, Kulkarni M V. Study of mycotic keratitis. Indian J Ophthalmol 1985;33:229-231.

11. Sharma S, Srinivasan M, George C. The current status of Fusarium species in mycotic keratitis in south India. Indian J Med Microbiol 1993;11:140-147.

12. Chander J, Sharma A. Prevalence of fungal corneal ulcers in Northern India. Infection 1994;22:207-209.

13. Dutta LC, Dutta D, Mohanty P, Sharma J. Study of fungal keratitis. Indian J Ophthalmol 1981;29:407-409.

14. Varenkar MP, Borkar Shubhangi, Pinto MJM, Naik PA. Study of mycotic keratitis in Goa. Indian J Med Microbiol 1998; $16: 58-60$

15. Srinivasan M, Gonzales CA, George C, et al. Whitcher Epidemiology and aetiological diagnosis of corneal ulceration in Madurai, south India. Br J Ophthalmol 1997;81:965-971.

16. Gopinathan U, Garg P, Fernandes M, et al. The epidemiological features and laboratory results of fungal keratitis: A 10 -year review at a referral eye care center in South India. Cornea 2002;21:555-559.

17. Fong CF, Tseng $\mathrm{CH}$, Hu FR, et al. Clinical characteristics of microbial keratitis in a university hospital in Taiwan. Am J Ophthalmol 2004;137:329-336.

18. Mirshahi A, Ojaghi $H$, Aghashahi D, Jabarvand M. Fungal dermatitis in patients at Farabi Hospital, Tehran. Bina 1999;5:135-143.
19. Javadi MA, Hemati R, Muhammadi MM, et al. causes of fungal corneal Keratitis and its management. Review of 23 cases from Labafinejad Medical Center (LMC). Bina 1996;2:3854.

20. Bharathi M J, Ramakrishnan R, Vasu S, et al. Epidemiological characteristics and laboratory diagnosis of fungal keratitis: A three-year study. Indian J Ophthalmol 2003;51:315-321.

21. Narsani AK, Nangdev PR, Surhio SA, et al. Demographic pattern, risk factors, clinical and microbiological characteristics of fungal keratitis. JLUMHS 2012;11:42-46.

22. Chander J, Singla N, Agnihotri N, et al. Keratomycosis in and around Chandigarh: A five-year study from a north Indian tertiary care hospital. Indian J Pathol Microbiol 2008;51:304306.

23. Kunimoto DY, Sharma S, Garg P, et al. Corneal ulceration in the elderly in Hyderabad South India. $\mathrm{Br} \mathrm{J}$ ophthalmol 2000;84:54-59.

24. Hagan M, Wright E, Newman M, et al. Causes of suppurative keratitis in Ghana. Br J Ophthalmol 1995;79:1024-1028.

25. Forster RK, Rebell G. The diagnosis and management of keratomycoses. Arch Ophthalmol 1975;93:975-978.

26. Thylefors B. Epidemiological patterns of ocular trauma. Aust NZ J Ophthalmol 1992;20:95-98.

27. Upadhyay MP, Karmachanya PCD, Koirala S, et al. Epidemiologic characteristics, predisposing factors, and etiologic diagnosis of corneal ulceration in Nepal. Am J Ophthalmol 1991;111:92-99.

28. Schaefer F, Bruttin O, Zografos L, Guex-Crosier Y. Bacterial keratitis: a prospective clinical and microbiological study. $\mathrm{Br}$ J Ophthalmol 2001l;85:842-847.

29. Kotigadde S, Ballal M, Jyothirlatha, et al. Mycotic keratitis : A study in coastal Karnataka. Indian J Ophthalmol 1992;40:3133. 